\title{
LEADER-MEMBER EXCHANGE, CREATIVE WORK INVOLVEMENT: THE IMPORTANCE OF ORGANIZATIONAL FORGETTING
}

\author{
Habibollah Salarzehi $^{* a}$, Jaleh Farzaneh Hassanzadeh ${ }^{\mathrm{b}}$, Habib Ebrahimpour ${ }^{\mathrm{c}}$ \\ a. Associate Professor of Management, University of Sistan and Baluchestan Zahedan, Iran \\ b. Phd student, University of Sistan and Baluchestan, Zahedan, Iran. \\ c. Faculty of Education and Psychology, University of Mohaghegh Ardabili, Ardabil, Iran
}

\begin{abstract}
An increasing number of organizations are turning to knowledge based organizations. Thus, theses firms pay attention to innovation and creativity more and more. Therefore, this study focused on the mediating role of organizational forgetting in the LMX- creative work involvement relationship. Data $(\mathrm{N}=418)$ collected in knowledge based organizations in north of Iran and confirmed our assumptions on the mediating role of organizational forgetting. The indirect relationship between LMX and creative work involvement through organizational forgetting was stronger than direct effect. Our findings, point to the importance of considering the leader-member relationship and organizational forgetting issues for increasing employees' creative work involvement.
\end{abstract}

Key words: Leader-member exchange (LMX), Creative work involvement, Organizational forgetting, Intentional organizational forgetting.

\section{Introduction}

Todays, global companies have been exposed to rapid changes, they need employees who search for new opportunities and who continuously improve their work environment (Oldham \& Cummings, 1996; Rank, Pace \& Frese, 2004; Unsworth, 2001). Especially, in a knowledge -based economy, organizations face rising needs to increase not only productivity among their workers, but also their creativity. The speed of technological change as well as globalization and increasing competition, both domestically and internationally, has put enormous pressure on companies to be first- to market, quick to solve problems, and ready to develop new small group of individuals working 
together (Amabile, 1988, p.126 cited in Atwater \& Carmeli, 2009) has rapidly become a key goal of many organizations (Mumford, Scott, Gaddis \& Strange, 2002). Leaders are thought to be one of the most influential predictors of creativity work (Mumford, Scott Gaddis \& Strange, 2002; Rosing, Frese $\&$ Bausch, 2011). Therefore, leaders need to know how to provide a context for employees' creativity in order to stay competitive in today's turbulent and fast-changing work environments (Tierney, 2008). Furthermore, it is almost the dominant view among leaders that knowledge is one of the most important competitive advantage of firms in today economic competitiveness (Davenport \& Prusak, 1998; Mayo \& Lank, 1994). In a broad view toward knowledge , there is little doubt that today's competitive advantage of all economic units, individuals (Drucker,1999), firms (Davenport \& Prusak,1998), and nations (Stevens , 1998 ; Foray,2000; Lundvall \& Archibugi, 2001) is highly related to their capabilities of managing their knowledge. Accordingly, the process of developing and utilizing such valuable source of competitiveness, learning, would be the most important agenda of firms in such knowledge - based competitive market. The very influential role of knowledge in all aspects of life lead us to overlook the fact that companies do not just learn; they also forget (Deholan, Phillips \& Lawerence, 2004). Organizational forgetting is important and essential because organizational learning and creative work mostly depend on organizational forgetting processes. It means that the companies, which intend to change themselves, not only need new abilities, but also forget the old knowledge which restricted them in the past (Esfahani, Radmehr \& Hatampoor, 2012). Therefore, the current study examine how leader-member exchange (LMX) quality impact followers' creative work involvement by mediator role of organization forgetting (International organizational forgetting).

\section{Leader-member exchange quality}

Leader - member exchange (LMX) theory describes leadership as a process, focusing on the relationship between a leader and follower (Gerstner \& Day, 1997; Liden, Sparrowe \& Wayne, 1997). Byrne (1971) explained that when a leader and a follower share similar attitudes, opinions, and beliefs, their relationship would be more positive (cited in Barbuto \& Gifford, 2012). From this similarity attraction paradigm, Danserea, Graen and Haga (1975) developed vertical dyad linkage theory to depict the leader-follower relationship. Danserea etal's findings indicated that leaders fostered differentiated dyadic exchanges with individual followers based upon similarities and differences.

In its infancy, LMX research categorized the relationship leaders could have with their followers into two groups: the in-group and out group, more recently referred to as high-quality and low-quality exchange respectively (Graen \& Uhl-Bien, 1995; Liden etal., 1997). Research on leader-member exchange (LMX) has shown the value of high-quality leader-member relationships in organizations (Grean \& Uhl-Bien, 1995; Liden, Sparrowe \& Wayne, 1997; Maslyn \& Uh-Bien, 2001). A high quality exchange relationship requires both parties accept their mutual- interests and agree to pursue shared superordinate goals. High- quality have been described as a partnering of colleagues, where individuals step beyond formal organizational roles to achieve desired goals ( Graen \& Uhl-Bien, 1995 cited in Fisk \& Friesen, 2012). In contrast, leaders and followers in low-quality relationship closely adhere to their respective organizational roles and do not step beyond those bounds. Also, managers exhibits low levels of mutual trust, respect, and obligation toward members (Barbuto \& Gifford, 2012).

\section{LMX and Creative work Involvement}

Although researchers have long been interested in the antecedents and consequences of job involvement (Carmeli, 2005), relatively little is known about involvement in creative work, i.e., "the 
extent to which an employee engages his or her time and effort resources in creative processes associated with work (Carmeli \& Schaubroeck, 2007, p. 36). Also, researchers have argued that it is not only important to consider outcomes of creativity, such as the actual idea or solution, but that it is of special importance to gain knowledge about employees' evaluation of creative involvement at work ( Atwater \& Carmeli, 2009; Carmeli \& Schaubroeck, 2007; Kark \& Carmeli, 2009 ).According to Ohly etal. (2006), creative work involvement is regarded as an important precursor of creative outcomes because it is strongly related to creative performance and innovation (Volmer, Spurk \&Niessen, 2012).

Leaders are thought to be one of the most influential predictors of creativity at work (Mumford, et al., 2002; Rosing, Frese \& Bausch, 2011). Thus, researchers have begun investigating the impact of leaders on creativity, including studies that have considered leader and follower traits (Tierney, Farmer \& Graen, 1999 ; Zhou \& George , 2003) , transformational leadership (e.g. Jaussi \& Dionne , 2003; Jung, chow \& Wu , 2003), benevolent leadership (Wang \& Cheng , 2010), and empowering leadership (Zhang \& Bartol, 2010a). Also, researchers have also started examing the association between a relational concept of leadership, namely leader-member exchange (LMX) and creativity (e.g. Atwater \& carmeli,2009 ; Volmer etal., 2012 ; Scott \& Bruce , 1994 ; Tierney etal. , 1999). According to Graen \& Schiemann, LMX theory differs from other leadership approaches by its explicit focus on unique, dyadic relationships and the notion that leaders and followers negotiate their relationship over time (Volmer etal, 2012).

Theoretically, researchers have suggested a number of reasons for a positive LMX- creativity relationship. For example, employees in high -quality relationships are considered to be more creative compared to their less-privileged colleagues because of their more focused approach to challenging and difficult tasks, together with their greater risk-taking, and the fact that employees in high-quality LMX relationships receive more task-related recognition, interpersonal support and appreciation (Tierney, 2008; Tierney, Farmer \& Graen, 1999). Moreover, researchers have suggested that LMX is beneficial for innovation because enjoying a good LMX relationship is accompanied by encouraging climate perceptions (Scott \& Bruce, 1994). The experience of an encouraging social climate is important for employees' creative work involvement (Kark \& Carmeli, 2009). LMX research has also shown that employees who enjoy a high-quality LMX relationship feel obliged to reciprocate to their supervisors by engaging in discretionary processes at work (IIies, Nahrgang \& Morgeson, 2007). Therefore, in this study we examine a direct relationship between LMX and creative work involvement.

Hypothesis 1: The quality of leader-member exchange (LMX) will be positively related with creative work involvement.

\section{Mediating role of organizational forgetting}

Knowledge management, as one of the most important organizational components, needs founding a system to learn, gathers, keep and spread knowledge inside the organization (Esfahani et al., 2012). Also, based on works by Dierickx and Cool (1989), Decarolis and Deeds (1999) and others, organizational knowledge can be represented as stocks of knowledge that grow through flows of increasing knowledge (organizational learning) and shrink through flows of depreciating knowledge (organizational forgetting ) (cited in Fernandez \& Sune, 2009). Scientific research on knowledge management has focused on the processes of knowledge creation, use and transfer, but has devoted little attention to the processes of organizational forgetting. However, it must be considered as a strategic agenda.

Organizational forgetting has been defined as the intentional or unintentional loss of organizational knowledge at any level (Martin \& Phillips, 2003). Furthermore, in the field of 
organization theory, organizational forgetting has been studied mainly from two standpoints. The first standpoint sees accidental or unwanted forgetting as a degradation of the stocks of organizational knowledge. The second standpoint considers forgetting as an intentional process of unlearning preceding organizational learning (Fernandez \& Sune, 2009). Considering these two aspects, there are four types of organizational forgetting (See table 1).

Table1. Organizational forgetting types (Deholan Phillips \& Lawrence, 2004).

\begin{tabular}{|l|l|l|}
\hline Forgetting method & Old & New \\
\hline Accidental & Destroying memory & Inability gaining knowledge \\
\hline Intentional & Cleaning learning & Avoiding bad habits \\
\hline
\end{tabular}

Destroying memory happens when the knowledge, which is saved in organizational memory system, destroys gradually. moreover, inability in gaining knowledge is unable to keep the new knowledge which has been transferred from outside to organization and has been created inside the organization. Also, cleaning learning happens when the knowledge which is present in organization is removed knowingly from organizational memory. Finally, avoiding bad habits happen when organization can learn bad habits, instructions, deeds, beliefs and values which are harmful for production (Deholan, Phillips \& Lawrence, 2004).

In this study, intentional dimension of organizational forgetting has been examined. Because managing old, absolete and harmful knowledge in organizations can reduce potential negative impacts of such knowledge in organizational performance (Tsang \& Zahra, 2008; DeHolan \& Filiphs, 2005).

Organizational forgetting, especially intentional organization forgetting, is effective on the competitiveness of an organization and generally, proper managing of organizational forgetting is an unavoidable affair to increase the competitiveness of organizations in today's rough environment. According Esfahani et al. (2012), there is a positive and meaning full relationship between organizational forgetting and situational leadership style (Selling, participation and delegation leadership style). Also, Nystrom and Starbuck (1984):58) suggest that the way to unlearn during an organizational crisis is by removing top managers as a group. This is because top managers are bolstered by previous successes and adamantly cling to their beliefs and perceptions, therefore rationalizing their organizations' failures. Change in ownership is often another trigger of forgetting (Markoczy, 1994).

Thus, leadership is an important factor for learning or unlearning of a firm. However, in this study, the effect of LMX has been examined on organizational forgetting. Because a high-quality relationship, as characterized by favorable reciprocal exchanges between leader and member (Volmer et al. , 2012), is associated with numerous positive outcomes, such as better performance, more commitment, job satisfaction, and a higher degree of mutual liking (IIies et al. , 2007 ; Liden et al., 1997). These factors can lead to increase employees' positive actions like intentional knowledge forgetting.

Hypo thesis 2: The quality of leader-member exchange (LMX) will be positively related with intentional knowledge forgetting.

The speed and innovation of companies rely more and more on knowledge and creativity. But knowledge and innovation process in organizations are astounding with information. Nothing is as fast outdated as information. The stress should be on innovative capacity (Dhondt, 2005). One of factors can limit the innovative capacity in an organization is the oldness and uselessness of current technical and non-technical knowledge (Bagherzadeh Niri, Akhavan \& Hosnavi \& Atashgah, 2010). Thus, organizational forgetting, especially, intentional organizational forgetting can be useful for 
increase of employees' innovative capacity, as Fernandez and Sune (2009) conceded that organizational forgetting is in relation with innovation .

Hypothesis 3: The intentional organizational forgetting will be positively related with creative work involvement.

Researchers point out leaders can promote creativity among followers by providing them with the resources. They need for creative task. Creativity requires time and effort, and leaders can help followers by procuring essential resources such as materials, funding, and access to information and knowledge (Keiter-Palmone \& IIIies, 2004). Therefore, Intentional organizational forget can mediate the relationship between LMX and creative work involvement.

Hypothesis 4: Through the mediating effect of intentional organizational forgetting, the quality of leader-member exchange (LMX) will enhance creative work involvement.

\section{Research method}

\section{Overview}

This research studied the relationship between leadership-member exchange quality, organizational forgetting and creative work involvement. From what has been discussed above, the study established a basic research model. Fig.1 shows that leadership-member exchange is independent variable, organizational forgetting is the mediator variable and eventually creative work involvement is the dependent variable.

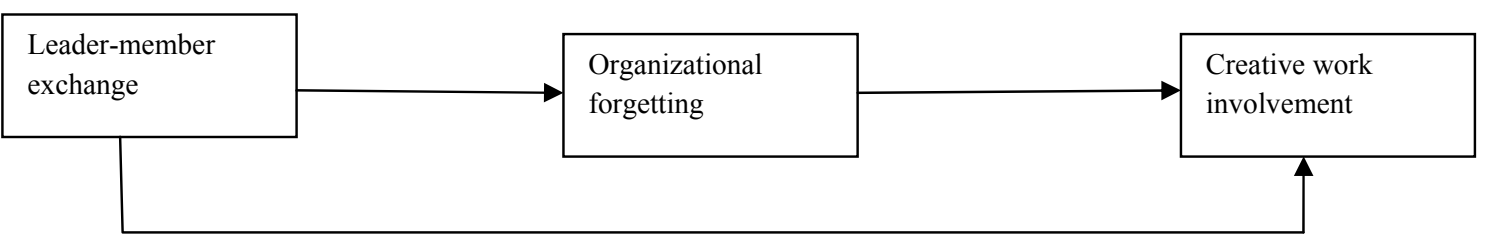

Fig.1. Conceptual framework of the research

The data were collected from employees in insurance companies in northeast of Iran through a questionnaire with three sections. . Leader-member was adapted from the 7-item measure from Graen and UhI-Bien (1995). Employee involvement in creative work was adopted from the 9- item measure developed used by Tierney, Farmer and Graen (1999). Finally, following pervious research ( e. g. , Lee , 2001), 13- item were used to measure intentional organizational forgetting . Also, questionnaire was answered on a 5 - point likert type scale varying in 5 differing response sets. Furthermore, the study used Spss 20 for descriptive statistic analysis; AMOS 7 was used for confirmatory factor analysis and structural equation modeling.

\section{Results}

Respondent profile

After we obtained constant from managers to allow their employees to participate in our study, total of 520 randomly selected employees. 418 complete and valid questionnaires were received as the response. Regarding demographics, $62 \%$ of the employee respondents were male with an average age of 28.55 years $(\mathrm{SD}=9.34)$. $76.53 \%$ of participants possessed bachelor's degree. Moreover, their average work experience was 7.06 years. 
Table1. Respondents' profile

\begin{tabular}{|c|c|c|}
\hline & Frequency & $\%$ \\
\hline \multicolumn{3}{|l|}{ Gender } \\
\hline Male & 259 & 62 \\
\hline Female & 159 & 38 \\
\hline Total & 418 & 100 \\
\hline \multicolumn{3}{|l|}{ Age (yr) } \\
\hline 25 or under & 77 & 18.42 \\
\hline $26-35$ & 225 & 53.83 \\
\hline $36-45$ & 102 & 24.40 \\
\hline $46-55$ & 12 & 2.87 \\
\hline 56 or above & 4 & 0.96 \\
\hline Total & 418 & 100 \\
\hline \multicolumn{3}{|l|}{ Education } \\
\hline Less than secondary/high school & - & - \\
\hline Secondary/high school & 10 & 2.39 \\
\hline Some college or university & 72 & 17.22 \\
\hline College/university diploma/degree & 319 & 76.31 \\
\hline Postgraduate degree & 17 & 4.06 \\
\hline Total & 418 & 100 \\
\hline \multicolumn{3}{|l|}{ Years of service } \\
\hline 5 or less & 66 & 15.89 \\
\hline $5-10$ & 198 & 47.37 \\
\hline $11-15$ & 92 & 22 \\
\hline $16-20$ & 48 & 11.48 \\
\hline $21-25$ & 10 & 2.39 \\
\hline 26 or above & 4 & 0.96 \\
\hline Total & 418 & 100 \\
\hline
\end{tabular}

\section{Descriptive analysis}

Table 2 displays means, standard deviations and correlations among study variables. Leadership member exchange quality had a significant correlation with organizational forgetting and creative work involvement $(\mathrm{r}=0.514, \mathrm{p} \leq 0.01, \mathrm{r}=0.452, \mathrm{p} \leq 0.01)$. Creative work involvement also, had significant positive correlations with organizational forgetting $(\mathrm{r}=0.459, \mathrm{p} \leq 0.001)$. Moreover, The Cronbach's alpha values of research variable were in the range of $0.68-0.89$, indicating good reliability (Nunnally, 1976).

Table2. Descriptive analyses

\begin{tabular}{|c|c|c|c|c|c|}
\hline $\mathrm{N}=418$ & Mean(S.D.) & Cronbach's $\alpha$ & Correlations & & \\
\hline & & & 1 & 2 & 3 \\
\hline 1.LMX & $4.15(1.03)$ & 0.89 & 1 & & \\
\hline $\begin{array}{l}\text { 2.organizational } \\
\text { forgetting }\end{array}$ & $3.18(0.78)$ & 0.68 & $0.514^{*}$ & 1 & \\
\hline $\begin{array}{l}\text { 3. creative work } \\
\text { involvement }\end{array}$ & $4.56(0.57)$ & 0.78 & $0.452 *$ & $0.459^{*}$ & 1 \\
\hline
\end{tabular}




\section{Confirmatory factor analysis}

Before testing the hypotheses of this study, LISREL 8.8 is used to conduct confirmatory factor analysis on the three research variable (LMX, Knowledge sharing, Creative work involvement). This aims to verify the construct validity of the research concepts. Questions used in this study have considerable content validity. Table 3 shows that the standardized factor loadings of observed variables to their latent variables ranged from $.56-.88$ and results of t test all reached the level of significance. This shows that the observed variables are adequate to reflect the constructed latent variables are adequate to reflect the constructed latent variable (Bentler \& Wu, 1983; JÖreskog \& SÖrbom, 2006). In a further step, composite reliability (CR) and the average amount of variance extracted (AVE) are used to check the reliability and validity of the scale. Hair etal., (1998) proposed that the CR value must be greater than 0.7 and Fornell and Larcker (1981) suggested the AVE value must be greater than 0.5 . The latent variables $\mathrm{CR}$ value derived from the studies in this research falls in between 0.78-0.96 and AVE value 0.59-0.69. This shows that the latent variables in this study have good consistency, reliability and convergent validity.

Table3. Confirmatory factor analysis on measurement variables

\begin{tabular}{|c|c|c|c|c|c|}
\hline Latent variables & Items & $\begin{array}{l}\text { Standardized } \\
\text { parameter s }\end{array}$ & t-value & $\mathrm{CR}$ & AVE \\
\hline \multirow[t]{7}{*}{$\begin{array}{l}\text { Leader- member } \\
\text { exchange }\end{array}$} & Q1 & .67 & 6.18 & & \\
\hline & Q2 & .73 & 6.25 & .96 & .66 \\
\hline & Q3 & .67 & 6.86 & & \\
\hline & Q4 & .85 & 7.72 & & \\
\hline & Q5 & .68 & 10.82 & & \\
\hline & Q6 & .84 & 9.71 & & \\
\hline & Q7 & .88 & 10.32 & & \\
\hline \multicolumn{6}{|l|}{ Organizational } \\
\hline \multirow[t]{12}{*}{ forgetting } & Q8 & .73 & 8.46 & & \\
\hline & Q9 & .68 & 6.58 & & \\
\hline & Q10 & .77 & 6.16 & .78 & .59 \\
\hline & Q11 & .84 & 8.43 & & \\
\hline & Q12 & .85 & 9.76 & & \\
\hline & Q13 & .76 & 6.63 & & \\
\hline & Q14 & .64 & 5.67 & & \\
\hline & Q15 & .56 & 6.78 & & \\
\hline & Q16 & .58 & 8.56 & & \\
\hline & Q17 & .68 & 6.78 & & \\
\hline & Q18 & .61 & 5.34 & & \\
\hline & Q19 & .83 & 5.78 & & \\
\hline \multirow{10}{*}{$\begin{array}{l}\text { Creative work } \\
\text { involvement }\end{array}$} & Q20 & .78 & 6.78 & & \\
\hline & Q21 & .78 & 6.21 & & \\
\hline & Q22 & .74 & 6.53 & & \\
\hline & Q23 & .71 & 9.67 & & \\
\hline & Q24 & .63 & 10.14 & & \\
\hline & Q25 & .68 & 7.43 & .79 & .69 \\
\hline & Q26 & .72 & 8.98 & & \\
\hline & Q27 & .66 & 6.89 & & \\
\hline & Q28 & .85 & 7.88 & & \\
\hline & Q29 & .58 & 6.78 & & \\
\hline
\end{tabular}




\section{Hypotheses tests}

\section{Measurement model}

We used structural equation modeling with LISREL 8.8 (JÖreskog \& SÖrbom, 2006) to test our hypotheses. Prior to testing the hypothesized structural model, we tested to see if the measurement model had good fit (Anderson \& Gerbing, 1988). We tested a measurement model that had three latent factors (i.e. LMX, organizational forgetting, creative work involvement). The measurement model had an acceptable fit ( $\mathrm{x} 2=741.06, \mathrm{df}=225, \mathrm{p} \leq 0.01$; NNFI $=0.98, \mathrm{GFI}=0.93, \mathrm{CFI}=0.94$, RMSEA= 0.09 ; SRMR= 0.06) ( Arbuckle , 1997 ; Bollen , 1999 ; Browne \& Cudeck , 1993), and all of the indicators had statistically significant $(\mathrm{p} \leq 0.01)$ loading on their intended constructs.

\section{Hypothesized model}

Having confirmed that the measurement model had adequate fit, we tested our proposed structural model. Results of the structural analysis of the proposed model provides an acceptable fit to the data $(\mathrm{x} 2=740.71, \mathrm{df}=231, \mathrm{p} \leq 0.01 ; \mathrm{NNFI}=0.95, \mathrm{GFI}=0.93, \mathrm{CFI}=0.94, \mathrm{RMSEA}=0.09, \mathrm{SRMR}=0.06)$ (Arbuckle, 1997; Bollen, 1989; Browne \& Cudeck, 1993; Hox, 2002).

Table4. Goodness- of fit indicators for the measurement and structural model

\begin{tabular}{llll}
\hline Indicators of goodness fit & Measurement model & Structural model & Proposed \\
\hline $\mathrm{x} 2$ / df & $741.06 / 225=$ & $740.71 / 231=$ & $\leq 3$ \\
NNFI & 0.98 & 0.95 & $\geq 0.9$ \\
GFI & 0.95 & 0.93 & $\geq 0.9$ \\
CFI & 0.96 & 0.94 & $\geq 0.9$ \\
RMSEA & 0.09 & 0.09 & $\leq 0.08$ \\
SRMR & 0.06 & 0.06 & $\leq 0.08$ \\
\hline
\end{tabular}

In support of hypothesis 1 , the path coefficient between LMX and creative work involvement was positive and significant $(\beta=0.25, \mathrm{p} \leq 0.001)$. Hypothesis 2 predicted that LMX is positively related to organizational forgetting. We also, found support for this hypothesis ( $\beta=0.59, \mathrm{p} \leq$ 0.001).Furthermore, organizational forgetting significantly and positively affected creative work involvement $(\beta=0.46, p \leq 0.001)$, thereby hypothesis 3 is supported . Hypothesis 4 predicted that organizational forgetting mediates the relationship between LMX and creative work involvement. To test for mediation, James et al. (2006) provided some recommendations. First, a statistically significant relationship must exist between the predictor and the mediator. Second, a statistically significant relationship must exist between the mediator and the outcome. Finally, a goodness- of fit test is conducted to determine whether the only path from the predictor to the outcome is through the mediator.

The study provided support for organizational forgetting as a mediator of the relationship between LMX and creative work involvement. Due to a statistically significant indirect effect implies that the relationship between the antecedent and the outcome variable occurs through the mediator $(0.69 \times 0.46 \geq 0.25)$. Thus, the study validated hypothesis 4 .

Table5. Summary of hypothesis results

\begin{tabular}{llll}
\hline Latent independent variable & Latent dependent variable & Path coefficient & t-value \\
\hline LMX & Creative work involvement & 0.69 & 3.56 \\
LMX & Organizational forgetting & 0.25 & 2.84 \\
Organizational forgetting & Creative work involvement & 0.46 & 3.22 \\
& & & \\
\hline
\end{tabular}




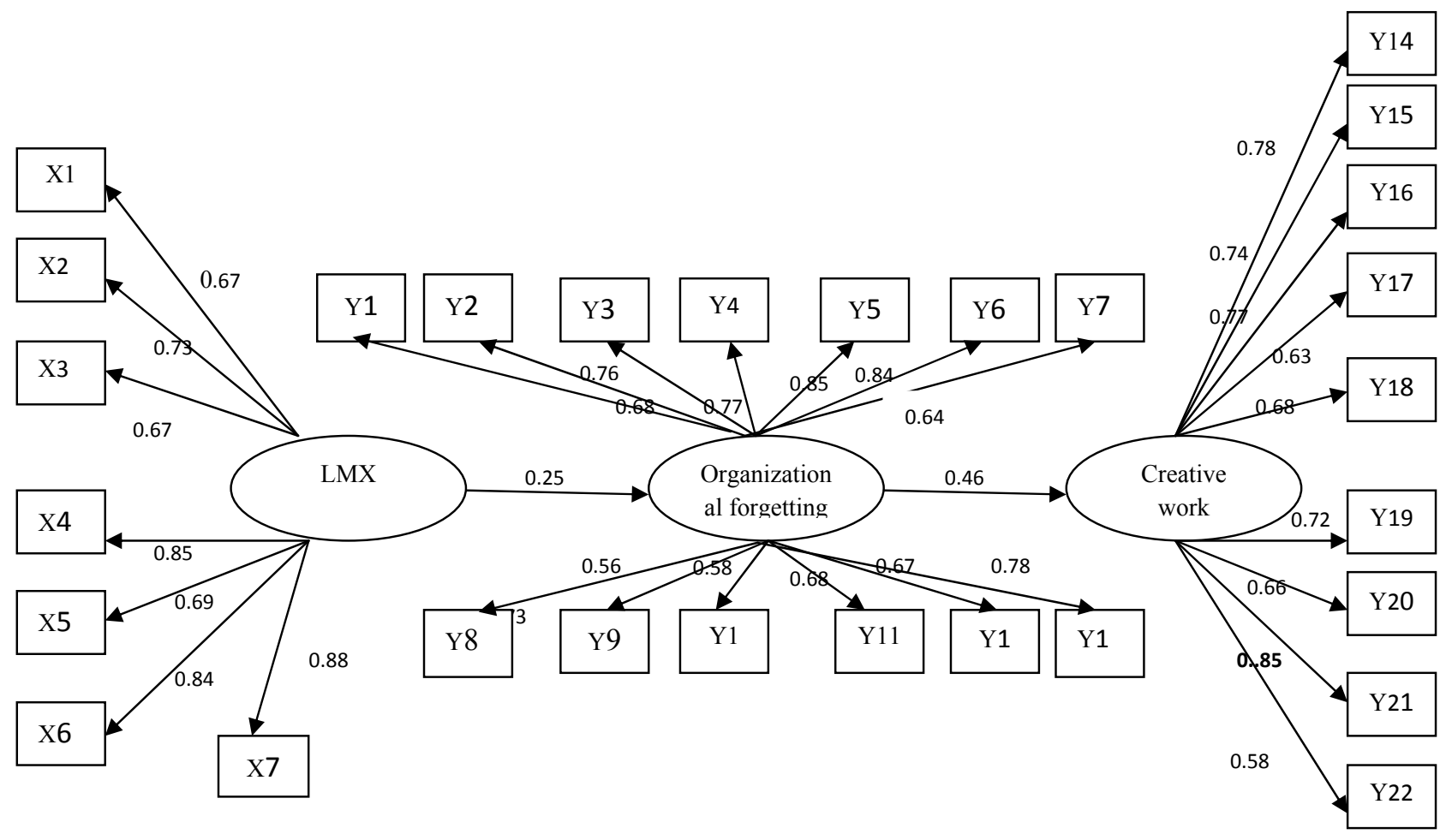

$\mathrm{P}<0.01$

Fig.1. Structural model

\section{Discussion}

We sought whether relationship quality (in terms of leader -member exchange; LMX) was associated with creative work involvement, and whether organizational forgetting mediates this relationship. Our findings show that LMX was positively related with creative work involvement. Furthermore, LMX was positively related to organizational forgetting, organizational forgetting was positively related to creative work involvement. Also, and most importantly, our results yielded support for our postulated effect of mediating role of organizational forgetting. Thus, organizational forgetting mediated the relationship between LMX and creative work involvement. Researchers suggest a more detailed exploration of the LMX- creative work involvement relationship (Atwater \& Carmeli, 2009; Tierney, 2008; Kark \& Carmeli, 2009). For example, the findings of Volmer et al. (2012) indicated that high quality of supervisor-employee relationships( i.e. , leader-member exchange; LMX) fosters creativity at work The findings of Volmer et al. (2012) indicated that high quality of supervisor-employee relationships( i.e., leader-member exchange; LMX) fosters creativity at work . Moreover, Carmeli and Schaubroeck (2007) confirmed that the perceived expectation of the leader can influence individuals' creative involvement at work. As a result, high quality connections at work could be relevant for work and job involvement (Kark \& Carmeli, 2009; IIies et al., 2007).

On the other hand, nowadays organizations must consider knowledge and the most valuable and strategic resource for themselves and believe that in order to remain competitive. They should manage their capabilities and mental resources and leadership is the most important factor in knowledge management ( Esfahani et al. , 2012). This study confirmed that high quality of leader-member exchange can strengthen the intentional of organizational forgetting. Connections between supervisor and employees can facilitate the process of knowledge active forgetting in order to increase efficiency and effectiveness in an organization. Additionally, the finding that organizational mediates the relationship between LMX and work involvement. Because leaders in organizations are in positions 
to help manage knowledge resource. They can enforce a context of cooperation and structure the process of knowledge. Similarly, recent studies have pointed to the importance of high-quality work relationships for promoting learning and knowledge creation process (Volmer et al., 2012; Carmeli, Brueller \& Dutton, 2009). Furthermore, Fernandez and Sune (2009) explained that forgetting is closely related to innovation. This study, in addition to confirmed this result, examined the mediating role of knowledge forgetting and conceded that the high quality of leader-member exchange can fortify intentional fortify intentional forgetting knowledge in organization and subsequently enhance the employees' creative work involvement.

\section{Conclusion}

In a knowledge-based society, organizations seek ways to increase their innovations by fostering creative and innovative behaviors at work (Ford, 1996; Scott \& Bruce, 1994). One way is to better understand how managing knowledge in organization. Also, leaders are considered to be one of the most influential factors of creative work involvement. Therefore, in this study, we attempted to contribute to research on LMX and creative work involvement through intentional organizational forgetting. Using a sample of employees working in insurance companies in northeast of Iran, we sought to unravel the role of LMX in facilitating creative work involvement in organization. Our study showed that LMX directly and indirectly, through intentional organizational forgetting, augments creative work involvement. Thus, our study suggests that organizations should adopt an interactional approach in order to foster employees' creative work involvement. These findings highlight the fact that researchers and practitioners need to combine different research streams in an attempt to better understand what is needed for employees to involve creative works.

The results of this study lead to a number of avenues for future research. First, leaders can encourage in the work place using various tactics and behaviors. Certainly, there are other facets of leadership that foster creative activities (e.g. openness). Hence, one fruitful avenue for future research may be to identify a construct of creative leadership. Furthermore, we considered employee perceptions of LMX as an important mechanism for encouraging creative activities. However, future research should examine other dimensions of leader-member relationships that have the potential to encourage creativity. Moreover, in this study, we investigated mediating role of organizational forgetting which played a significant role in the LMX. Creative work involvement relationship. Although, other possible potential moderators, such as motivational orientations and feedback or collaboration structures should be investigated in future research.

\section{Reference}

Anderson, J. \& Gerbing, D. (1988), Structural Equation Modeling in practice: A Review and Recommended Two-Step Approach, Psychological Bulletin, 103, 411-423.

Arbuckle, J.L. (1997), Amos Users' Guide (Small Water Corporation, Chicago).

Atwater, Leanne; Carmeli, Abraham (2009), Leader-member exchange, feelings of energy , and involvement in creative work, The leadership Quarterly, 20 , 264-275.

Bagherzadeh Niri, Meh di ; Akhavan, Peyman; Hosnavi Atashgah, Reza (2010). Managing organizational knowledge active forgetting: How top managers understand the concept of managing old and obsolete knowledge, proceedings of the $11^{\text {th }}$ European Conference on Knowledge Management.

Barbuto, Jr.; John, E.; Gifford, Gregory T.(2012). Motivation and leader-member exchange: Evidence counter to similarity attraction theory, International Journal of Leadership Studies, 7(1), 18-28.

Browne, M.W \& Cudeck , R. (1993), Alternative Ways of Assessing Model Fit, in K.A. Bollen and L .J. Scott (eds.), Testing Structural Equation Models, ( Sage publications, Newbury park).

Brown, M.E; Trevino, L. K (2006). Ethical leadership: A review and future directions. The Leadership Quarerly, 17, 595616. 
Bollen, K.A.(1989). Structural Equation With Latent Variables (Wiley, NewYork).

Carmeli, A. (2005). Exploring determinants of job involvement: An empirical test among senior executives, International Journal of Manpower, 26, 457-472.

Carmeli, A.; Schaubroeck, K.J.(2007). The influence of leaders' and other referents' normative expectations on individual involvement in creative work, The Leadership Quarterly, 18 , 35-48.

Carmeli, A. ; Brueller, D. ; Dutton, J.E. (2009). Learning behaviors in the work place: The role of high-quality interpersonal relationship and psychological safety, systems research \& Behavioral Science, 26, 81-98.

Danseraa, Jr. F.; Graen, G.; Haga, W. J.(1975). A vertical dyad linkage approach to leadership within formal organizations: A longitudinal investigation of the role making process . Organizational Behavior and Human Performance, 13, 46-78.

Davenpourt, T.; Prusak , L. (1998). Working knowledge: How organizations manage what they know. Harvard Business School Press.

Decarolis, D.M.; Deeds, D.L.(1997). The impact of stocks and flows of organizational knowledge on firm performance: An empirical investigation of biotechnology industry, Strategic Management Journal, 20, 953-68.

Deholan, P.M; Phillips, N.; Lawrence, T.B.(2004). Management organizational forgetting. MIT Sloan Management Review, 45, 45-51.

Deholan, P. M; Filiphs, N. (2005). Organizational forgatting. In EASTERBY-SMITH, M. \& LYLES, M. A.(Eds.). The blackwell Handbook of Organizational learning and knowledge management. Oxford, Blackwell publishing, 393-409.

Dierickx, I; Cool, K (1989). Asset stock accumulation and sustainability of competitive advantage, Management Science, 35 , 1504-110.

Dohondt, Steven(2003), Knowledge management, innovation and creativity, TNO-report.

Drucker, P. (1999). Knowledge -worker productivity: The biggest challenge.California Management Review.

Esfahani, Ali Naser; Radmehr, Reza; Hatampoor, Fatemeh(2012). Studying the relationship between organizational forgetting and situational leadership style (Case of study: Qom's Melli Bank Branches), Australian Journal of Basic and Applied Sciences, 6 (9), 102-108.

Fernandez, Vicenc; Sune, Albert(2009). Organizational forgetting and its causes: An empirical research, Research paper, 129.

Fisk, Glenda M.; Friesen, Jared(2012). Perceptions of leader emotion regulation and LMX as predictors of followers' job satisfaction and organizational citizenship behaviours, The leadership Quarterly, 23, 1-12.

Foray, D.(2000). Rachid and Joe: on the essence of the knowledge economy. Paper presented at the paper for DRUID's Learning Economy Conference.

Ford, C. (1996). A theory of individual creative action in multiple social domains. Academy of Management Review, 21, $1112-1142$.

Gerstner, C.R.; Day, D.V. (1997). Mata-analytic review of leader-member exchange theory : Correlate, and construct issues , Journal of Applied Psychology , 82(6), 827-844.

Graen , G. B ; Uhl-Bien , M. (1995). Relationship - based approach to leadership: Development of leader-member exchange (LMX) theory of leadership over 25 years: Applying a multi-level, multi-domain perspective. The Leadership Quarterly, 6(2), 219-247.

Hox, J. (2002). Multilevel Analyses: Techniques and Applications (Lawrence Erlbaum Associates, Mahwah, NJ).

Ilies, R.; Nahrgang, J.D.; Morgeson, F. P. (2007). Leader-member exchange and citizenship behaviors: A meta-analysis, Journal of Applied Psychology, 92, 269-277.

James, L.R; Mulaik, S.A. \& Brett, J.M. (2006) . A Tale of Two Method, Organizational Research Methods, 9, $233-244$.

Jaussi, K.S.; Dionne, S.D. (2003). Leading for creativity: The role of unconventional leader behavior. The Leadership Quarterly, 14, 475-498.

JÖreskog, K.G.; SÖrbom , D. (2006). LISREL for windows (Scientific Software International, Inc . , Lincolnwood, IL).

Jung, D.I.; Chow, C. ; Wu , A. (2003). The role of transformational leadership in enhancing organizational innovation: Hypotheses and some preliminary findings. The Leadership Quarterly, 14, 525-544.

Kark, R. \& Carmeli, A. (2009). A live and creativity: The mediating role of vitality and aliveness in the relationship between psychological safety and creative work involvement, Journal of Organizational Behavior, 30, 785-804.

Liden, R.C.; Sparrowe, R.T.; Wayne, S.J. (1997). Leader-member exchange theory: The past and potential for the future. In G.R. Ferris (Ed.), Research in personnel and human resources management, 15, (pp. 47-119). Greenwich, CT: JAI Press Inc. 
Lundvall, B. A.; Archibugi, D.(2001). The globalizing learning economy Oxford university press.

Markoczy, L. (1994), Modes of organizational learning, International Studies of Management \& Organization, 24 , 5-30.

Maslyn, John M. ; Uhl-Bien , Mary (2001). Leader-member exchange and Its dimensions: Effects of self-effort and others' effect on relationship quality, Journal of Applied Psychology, 86(4), 697-708.

Martin de Holan, P.M.; Phillips, N.(2003). Organizational forgetting. In: The Blackwell handbook of organizational learning and knowledge management, M. Easterby-Smith \& M.A. Lyles (Eds.), 393-409, USA.

Martin de Heloan, P. M; Phillips, N.(2004). Remembrance of things past? The dynamics of organizational forgetting. Management Science, 50 (11), 1603-1613.

Mayo, A.; Lank , E. (1994). The power of learning: A Guide to gaining competitive advantage, St, Mut, London.

Mumford, M.D.; Scott, G.M.; Gaddis, B.; Strange, J.M. (2002), Leading creative people: Orchestrating expertise and relationships. Leadership Quarterly, 13, 705-750.

Nunnally, J.C., (1978). Psychometric theory, 2nd ed, McGraw-Hill, NewYork.

Nystrom, P.C; Starbuck, W.H.(1984). T avoid organizational crises - unlearn, Organizational Dynamics, 12, 53-65.

Oldham, G.R, \& Cummings, A.(1996). Employee creativity: Personal and contextual factors at work. Academy of Management Journal, 39, 607-634.

Rank, J.; Pace, V.L.; Frese, M.(2004). Three avenues for future research on creativity, innovation, and initiative. Applied Psychology: An International Review, 53, 518-528.

Reiter-Palmon , R. IIIies , J.J . (2004). Leadership and creativity: Understanding leadership from a creative problem-solving perspective. Leadership Quarterly, 15, 55-77.

Rosing, K.; Frese, M; Baisch, A. (2011). Explaining the heterogeneity of the leadership - innovation relationship: Ambidextrous leadership. The Leadership Quarterly, 22, 956-974.

Scott, S. G.; Bruce, R .A. (1994). Determinants of innovative in the workplace, Academy of Management Journal, 37, 580607.

Stevens, C. (1998). The knowledge-driven economy, In the knowledge, Economy, Boston.

Tierney, P. ; Farmer , S.M. ; Graen , G.B. (1999). An examination of leadership and employee creativity: The relevance of traits and relationships. Personnel Psychology, 52, 591-620.

Tierney, P. (2008). Leadership and employee creativity. In J. Zhou, \& C.E. Shalley (Eds). Handbook of organizational creativity(pp. 95-123). NewYork: Erl baum.

Tsang, E.W.k . ; Zahra , S.A. (2008) Organizational unlearning. Human Relations. 61(10), 1435-1462.

Unsworth , K. (2001). Unpacking creativity. Academy of Management Review, 26, 289-297.

Volmer, Judith; Spurk, Daniel; Niesseu, Cornelia (2012). Leader-member exchange (LMX), job autonomy, and creative work involvement, The leadership Quarterly, 23, 456-465.

Wang, A. C. ; Cheng, B.S. (2010). When does benevolent leadership lead to creativity? The moderating role of creative role identity and job autonomy. Journal of Organizational Behavior, 31, 106-121.

Zang, X.; Bartol, K.M. (2010 a) . Linking empowering leadership and employee creativity: The influence of psychological empowerment, intrinsic motivation, and creative process engagement . Academy of Management Journal, 53, 107128.

Zhang, X. M.; Batrol, K.M.(2010b). The influence of creative process engagement on employee creative performance and overall performance. Journal of Applied psychology, 95 , 862-873.

Zhou, J.; George, J.M.(2003). Awakening employee creativity: The role of leader emotional intelligence. The leadership Quarterly, 14 545-568. 